\title{
APSA Executive Director's Report, 2011
}

\author{
Michael Brintnall, APSA Executive Director
}

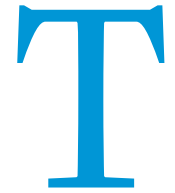

he annual executive director's report documents APSA's activities and directions for the year. The traditional core activities for a learned society are its journals and conferences. APSA, like its counterparts, also supports the discipline and the professional interests of members in a variety of ways: support for department chairs and academic programs, engagement with federal policymaking on support for scholarship and education, and attention to the pipeline of prospective new scholars in the discipline. Some of these initiatives focus on resources for individual political scientists, such as our mentoring initiative, and many are built around management of the commons of the discipline and efforts to assure that we collectively address matters that affect the discipline. APSA is active on many of these fronts, and this report in particular highlights those APSA activities that help support the disciplinary community as a whole.

\section{SUPPORT FOR DISCIPLINE IN PUBLIC EYE}

One component of APSA activities in support of the discipline is our advocacy efforts to protect and expand research funding in the discipline and intellectual efforts to advance the public understanding of political science and what it contributes to public life and policy. The October 2011 issue of the PS Supplement detailed steps in APSA advocacy efforts. While the debate on the federal budget continues, the longterm federal funding for social sciences and humanities remains precarious. APSA's efforts are concentrated on these political science research funding agencies: the National Science Foundation (NSF), National Institutes of Health (NIH), National Endowment for the Humanities, and US Department of Education. To aid APSA in monitoring these agencies, we have partnered with the Consortium of Social Science Associations that urges support for social science funding, particularly at NSF and NIH; the National Humanities Alliance that advocates on behalf of the National Endowment for the Humanities and relate organizations; and the Coalition for International Education that focuses on Title VI programs.

\section{UPDATE ON APSA INITIATIVES}

\section{Task Forces}

Substantively, APSA continues an initiative to name annual task forces, under the leadership of the president-elect, to report the contributions of the discipline on major public issues. Eleven such task forces have been named over the past decade with many reporting to the public with objective, balanced, and broad commentary on significant issues, such as the effects of income inequality on democratic governance or models of interdisciplinary research. Two task force reports emerged this year and another began.

One of the reports completed in 2011 is the APSA Task Force on Democracy, Economic Security, and Social Justice in a Volatile World, named by president Carole Pateman and chaired by Michael Goodhart, University of Pittsburgh. This report explored some of the tensions emerging in the relationship between democratic governance and goals of economic security and social justice. Furthermore, it considered innovations in areas of basic income, participatory budgeting and planning, and rights based models of welfare and development as prospects for reorienting assumptions about democracy and overcoming some of the failures of neoliberal and welfare state models for linking democracy with economic security and social justice. Information about the this task force and the status of their report is on the APSA website, http://www. apsanet.org/taskforces/.

Also this year, a task force, named by former president Dianne Pinderhughes, Political Science in the 21st Century issued its report, capped by a press conference at the National Press Club. This study focused on how the discipline is prepared to adapt to changing demographics, increasing multicultural diversity, and growing disparities in the concentration of wealth present in many nation-states. The study also considers the relevance of innovation in research agendas, curriculum, and demographics of the professoriate itself in response. This report, also posted online, has posed many challenges for the discipline.

Also, in 2011, president G. Bingham Powell, Jr. launched a new task force that will analyze the role of political science in configuring and refashioning electoral rules in aspiring and established democracies, titled Electoral Rules and Democratic Governance: Context and Consequences. The study, led by Mala Htun of the University of New Mexico, will assess the usefulness of political science research and strive to increase its relevance for important issues of the day. As the momentous events of the "Arab Spring" demonstrate, citizens everywhere demand inclusion, representation, accountability, and other benefits associated with democratic systems of government. Whether or not these claims can be met depends on, in part, the design and nature of the new institutions crafted by elites. Do these institutions reflect scientific knowledge and advice? Or does their design respond to other concerns? How can political scientists better assist in the planning of new democracies? This task force will focus on six areas of research: normative institutional design; ballot structure; rules, contexts, and outcomes; gender and ethnic inclusion; electoral rules and policy consequences; and the role of political scientists in electoral reform.

\section{Africa Workshop Project}

On another front, but in the same spirit of engagement, APSA sponsored, for the fourth consecutive year, a summer workshop for political scientists in Africa, jointly led by US-based and Africa-based political scientists, and held on the African continent. These workshops bring together 20 Africa-based early career scholars and four US-based advanced graduate students for two to three weeks of discussion and debate around a common theme, with the aim of supporting scholarly development and international research networks. The 2011 workshop, "Ethnic Politics and Africa's Governance Institutions in Comparative Context," was led by Todd Eisenstadt and Carl LeVan (both of American University), and by Karuti Kanyinga, University 
Figure 1

\section{Membership Chart}

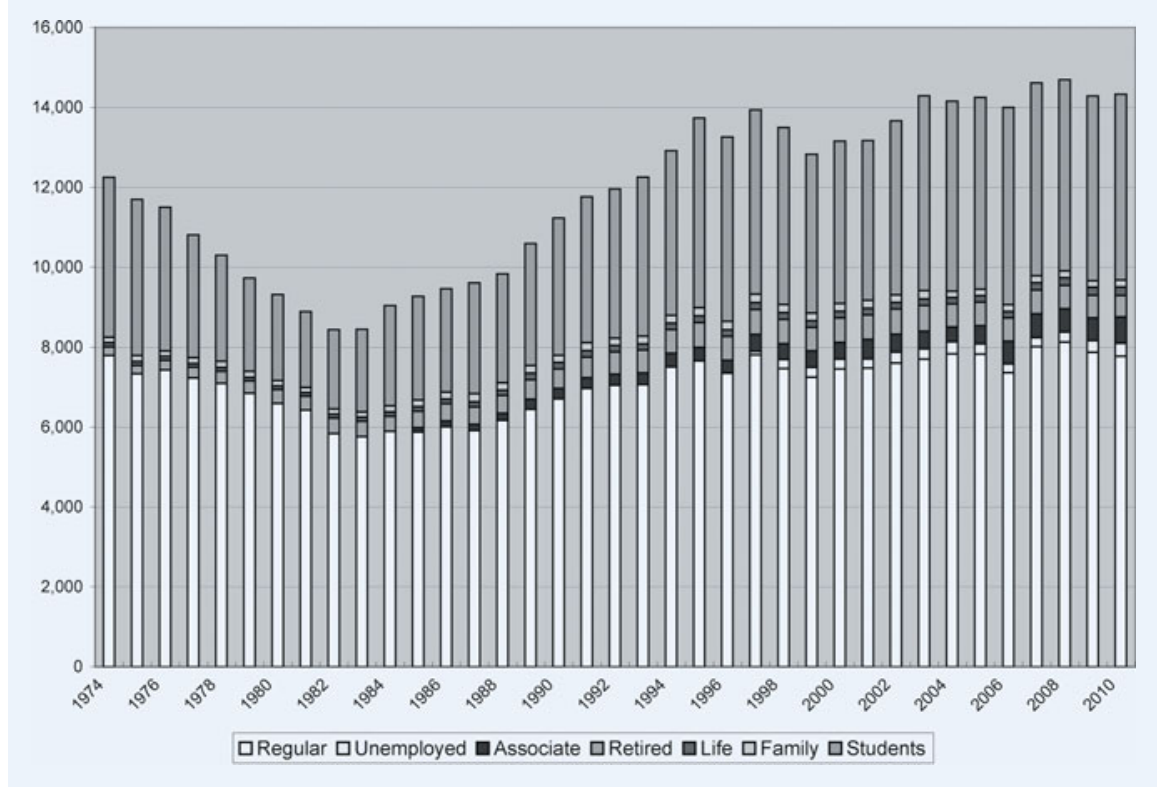

of Nairobi, and Tabitha Mulyampiti, Makerere University, Uganda. Workshop participants were hosted by the Institute of Development Studies at the University of Nairobi for two weeks. There, they explored the philosophical bases for representative democracy, processes of democratization, collective rights, identity, and broader theories of multiculturalism. Leveraging the different area expertise of the workshop leaders, seminars examined comparative cases from Latin America and Africa. The Africa workshops are generously supported by grants from the Andrew W. Mellon Foundation. In 2010, APSA was awarded a continuation grant to fund summer workshops through 2014, along with additional network programming for workshop alumni.

\section{Economic and Political Climate}

In an act of meta analysis, APSA has begun a project to better engage political science with the public. In January 2011, then APSA president Carole Pateman and former president Henry Brady co-named an Ad Hoc Committee on the Public Understanding of Political Science. The committee was given the task of producing "a set of recommendations by the end of FY2011 that provide the association with optional ways to promote the findings, scholars, and intellectual contributions of political scientists to Congress, the media, foundations, and the public at large." The committee will present its recommendations at the spring council meeting, and it should provide a blueprint for action to support political scientists' engagement with public matters in a wide variety of settings.

\section{Advancement of Profession}

APSA also has programs designed to help strengthen opportunities for political scientists in the discipline and to broaden opportunities for study and careers in political science. Led by the APSA Department of Education, Professional, and Diversity, the association has developed a series of new initiatives aimed at promoting professional development for undergraduate and graduate students and junior faculty. These events and initiatives, in part, are based on feedback from APSA committees and members, as well as trends in the discipline. Future programs include working with other APSA departments and committees to update the internship guide and the careers booklet, as well as a professional development webinar series. A listing of the student professional development events that took place at the 2011 Annual Meeting in Seattle, Washington, as well as details on other APSA student programming, follows.

APSA hosted the Second Annual Professional Development Roundtable at the 2011 Annual Meeting, "Professional Development and Academic Career Planning." The target audience included graduate students and junior faculty. The panelists discussed strategies for advancing to tenure; balancing research, teaching, and service; compiling a tenure folder; and networking. Panelists included G. Bingham Powell, Jr., University of Rochester; Lisa Garcia Bedolla, University of California, Berkeley; Kerry L. Haynie, Duke University; Paula D. McClain, Duke University; Tasha S. Philpot, University of Texas, Austin; and Timothy Kaufman-Osborn, Whitman College.

To better serve the APSA student community, APSA has been collecting responses and opinions of APSA students through the graduate student survey. As we work to provide additional resources, these responses help us to stay current with the education and professional needs of this segment of the APSA community. Students can access the survey through a link on the e-newsletter or by visiting the APSA graduate student connection web page, where information on APSA e-jobs, jobs placement, and mentoring is also located.

To further facilitate education about graduate programs in political science and graduate recruitment of all student groups, APSA hosted the first Annual Graduate School Information Fair at the 2011 Annual Meeting. Representatives from 12 graduate programs shared information about their political science programs with undergraduate students from Washington State and surrounding areas.

In the spring of 2011, APSA began showcasing faculty and departmental efforts to promote undergraduate research by highlighting individual and departmental undergraduate research initiatives and projects. APSA's recognition of these efforts was done in conjunction with the National Undergraduate Research Week.

\section{APSA Mentoring Program}

Over the last academic year, APSA has seen a marked growth in the number of APSA mentors. This growth is partly due to our increased outreach, follow-up evaluations, and program recruitment efforts such as systematic reminders and newsletter pieces. APSA mentors volunteer and are given the option of mentoring one or more mentees. There were 226 mentees matched with mentors between October 2010 and October 2011, an increase from the 141 matches that were made in 2009-2010. Currently, 306 APSA mentors are in the database. This number is down slightly from the 2010 figure of 317 APSA faculty mentors, but still an increase from the 2009 figure of 239 mentors. 
Since 2008, the APSA mentoring initiative has hosted the mentoring and networking reception at the APSA Annual Meeting. Current mentors and mentees are encouraged to attend; however, this event also allows for networking and professional development opportunities for the attendees. This outreach and networking event has been well-received by faculty and students alike. Recent updates to the mentor program include incorporating one-toone matches for Ralph Bunche Summer Institute and Minority Fellows Program Scholars.

APSA programs to support entrance and professional development of underrepresented students in the profession also moved forward during the year. These efforts include the APSA Minority Fellowship Program (MFP), APSA Ralph Bunche Summer Institute (RBSI), and the APSA Minority Student Recruitment Program (MSRP).

The goal of the MFP, established in 1969 as the Black Graduate Fellowship, is to increase the number of underrepresented students in political science doctoral graduate programs. In its 42 nd year, MFP has designated more than 500 fellows and has contributed to the successful completion of doctoral political science programs for more than 100 individuals. This year the MFP selection committee awarded the 2011-2012 APSA MFP fellowship to 12 students. These new fellows will also be matched with an MFP alumni through the APSA Mentoring Program. Each new MFP fellow receives a \$4,0oo award. Current MFP biographies are available on the APSA website at www.apsanet. org/mfp.

The Ralph Bunche Summer Institute (RBSI), created in 1986, is an intensive fiveweek academic and professional development program to assist in preparing a class of 20 students for graduate work in political science. The program provides academic credit, mentoring, and training in statistical analysis and the substantive area of race and ethnicity in political science. Under the leadership of Paula McClain and with the funding support of the National Science Foundation, Duke University, and APSA, this program has helped to simulate the graduate experience.

Since 1986, more than 400 students have attended the RBSI. A number of students who participate in RBSI go on to attend graduate school in political science, receive their PhDs, and enter the profes- soriate. In fact, several RBSI scholars have been awarded APSA minority fellowships. Since the 2007 Annual Meeting, APSA has coordinated a joint networking coffee hour at the Annual Meeting for RBSI scholars and APSA MFP fellows. Each year, 10 RBSI scholars are selected, based on their excellent final research projects at the RBSI, to present poster sessions at the APSA Annual Meeting. To view the list of scholars who presented at the 2011 Annual Meeting, visit www.apsanet.org/rbsi. During 2011-2012, APSA will be matching RBSI scholars with RBSI alumni, through the APSA Mentoring Program.

APSA established the Minority Student Recruitment Program (MSRP, formerly Minority Identification Project) as part of its efforts to advance the benefits of diversity within the political science profession. In collaboration with undergraduate and graduate political science departments, the program identifies undergraduate minority students who are interested in being recruited to doctoral programs and provides these students with information about political science graduate programs. Faculty or the interested students may submit their names to APSA so that they can be actively recruited by APSA member departments. There were 270 undergraduate students in the spring 2011 database and 267 in the fall 2011 database. Currently, 36 participating political science graduate departments are participating in the 2010-2011 MSRP (up from 33 last year). Recent programmatic updates have made it easier for graduate departments to submit their information online to become a recruiting department in the MSRP program. For a list of the 2010-2011 APSA Recruiting Graduate Departments in the MSRP, visit www.apsanet.org/msrp.

\section{Departmental Programs}

In 2011 APSA did not continue the standalone department chairs conference that had been offered for several years. Although the idea of the conference was widely received, attendance was low: few chairs were to schedule the time to travel. Instead, APSA is redoubling efforts to hold programs for chairs in conjunction with academic conferences, including the Teaching and Learning Conference, the Annual Meeting, and regional meetings. The centerpiece is the workshop for chairs at the APSA Annual Meeting. This year's workshop, "Unwitting Leader: How To Be an Effective Department Chair and Live to
Tell about It," included a separate panel, "A Glass Half Full: Finding a Job amid Uncertainty." In addition, a mini job fair and happy hour networking session that followed focused on nonacademic employment for political scientists.

The departmental services program is also advancing efforts to put data collection about departments on a more consistent and reliable track. It is also focused on publishing key guidelines for chairs. One project addresses a template of questions and guidelines for conducting external reviews of departments, with an eye to both thoroughness and to limited intrusion. Another project will update a chair's handbook, which has been in place for many years, and is being prepared as an online format with contributions by chairs about department leadership topics. It will be published in print in the spring, for members, as well as available online.

\section{Centennial Center for Political Science \& Public Affairs and the APSA Congressional Fellowship}

Intersecting between professional support and engagement of the discipline are two key APSA initiatives: the APSA Congressional Fellowship Program and the Centennial Center for Political Science \& Public Affairs. To take advantage of their basic synergy and to enhance the quality of both, as of September 2011, these two are now under the same APSA staffing direction. Over the past few years, for example, several Centennial Center scholars have become Congressional fellows-a practical legislative working experience that built on their more scholarly work at the Centennial Center.

Funding for the Centennial Center draws on 11 separate funds with their own inherent objectives that range across the broad expanse of the discipline. Since the center's inauguration in 2003, some 175 scholars have been supported residentially in the APSA offices or overseas. Several scholars have been supported by the Steiger Fund that was created specifically to support former APSA Congressional fellows. From October 2010 through October 2011, some 21 scholars have received center funding. In the months ahead, the international research funding potential should receive greater stress as it appears to be less well understood. Over this period, for example, the center combined its own support with outside funding so that a University of Notre Dame assistant professor could do 
Figure 2

\section{Annual Meeting Registration, 2011}

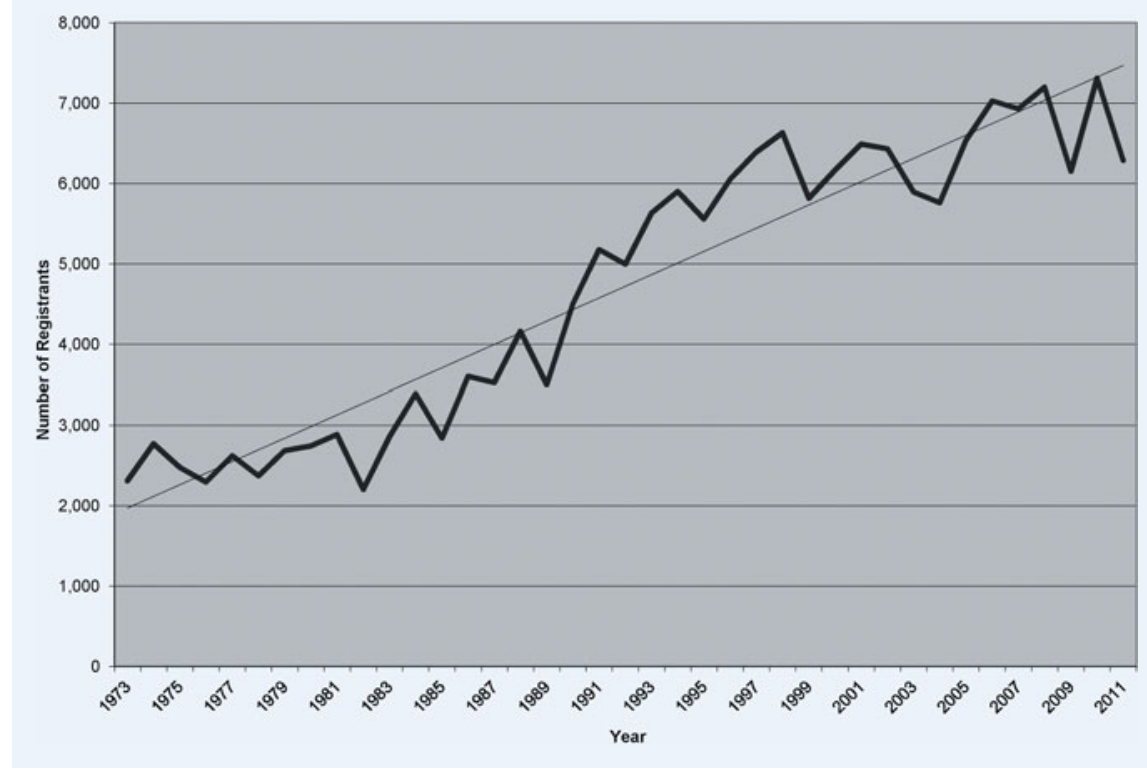

field research in Mali. In Mali she will distribute USAID-provided hand-cranked radios to rural women to test whether their greater access national and international news will bring them more into the political process of that African nation.

In a real sense we hope to transform the Centennial Center into something more far reaching than the Washington, DC, residential offices, desks, and computers that are basically representative of the past. APSA is less-equipped to compete with the infrastructure of our Dupont Circle neighborhood's think tanks and academic institutions such as the Carnegie Endowment, the Brookings Institution, or the Johns Hopkins School of Advanced International Studies. However, we are in a position to provide a small group discussion venue for topics reflected among our Centennial Center scholars and draw on the Congressional fellows as the nucleus of a mutually profitable exchange. As a trial run, the four scholars currently in residence at APSA agreed to brown-bag lunch discussions of their work during the November 2011 orientation with appropriate members of the Congressional Fellows. First, Montpellier French doctoral candidate Ulrike Lepont discussed her dissertation "The Role of Health Policy Experts in the Evolution of American Health Policy" with this year's Robert Wood Johnson (RWJ) Health Policy Fellows, the Institute of Medicine fellowship coordinators, the Atlantic Philanthropies
Health \& Aging Policy Fellows, the staff of AARP's policy office, and a selected group of local academics. Second, University of Cincinnati associate professor Dinshaw Mistry discussed "Domestic Politics and Foreign Policy: The Bush Administration, Congress, and the Civilian Nuclear Agreement with India" with this year's Congressional fellow foreign affairs seminar participants and their SAIS graduate school colleagues. Third, Takakazu Yamagishi, associate professor at Japan's Nanzan University discussed his research on the development of the USVeterans Administration health care program and its influence on the broader US health insurance system with the Congressional Fellowship health policy fellows and some of their colleagues who were placed last year in the Department of Health and Human Services' Medicare and Medicaid Services office. Finally, University of California, Santa Barbara doctoral candidate Anne Pluta's discussion "The Changing Dimensions of Popular Presidential Communication: Washington to Obama" was shared with this year's political scientist fellows and several specialists from the Congressional Research Service. In addition to these core groups, our Office of Departmental Services and the National Capital Political Science Association will invite a small group of local professoriate and graduate students.

As was true in 2010, several of the RWJ Health Policy fellows and Health and
Aging Policy fellows within the Congressional Fellowship Program are expected to opt for assignments in the executive branch, particularly the Department of Health and Human Services Office of Medicare and Medicaid Services to continue to help write the voluminous amount of regulatory and implementing language required for the administration's Affordable Health Act legislation-they will, however, go through the legislative interview process and attend the biweekly Wilson Seminar Series to provide as much congressional insights as possible. The exceedingly weak job market for journalists has led to fewer fellowship applications than in the past, and we have replaced that category with more political scientists-eight this year counting the Carl Albert Center Fellow. CFP continues to extend its reach, beyond the traditional "Americanists" with a legislative focus, into the comparative and international relations regions of the discipline. This change has led to some relatively untraditional selections including a US-naturalized Bosnian who was one of 10 international candidates at the US Air Force Academy who returned to Bosnia to fly helicopters for their air force. He married a US Air Force lieutenant colonel, decided not to continue to pursue nuclear physics at California Institute of Technology, and moved on to study international relations at the Pardee RAND Graduate School in California.

The Congressional Fellowship Program staff is currently working through the State Department's American Foreign Service Association union to put the APSA Congressional Fellowship Program on par with the Pearson Amendment fellows and thus attract more candidates. We are discussing with the Council for the International Exchange of Scholars the possible inclusion of some of the developing world's Humphrey Fellows into the APSA Congressional Fellowship.

\section{PROGRAMS FOR SCHOLARSHIP}

APSA programs for engagement and professional development wrap around core initiatives for scholarship and teachingthe APSA Annual Meeting, the Teaching and Learning Conference, and APSA's journals.

\section{Annual Meeting}

For the first time, APSA held its Annual Meeting in Seattle, Washington, bringing together political scientists from all over 
the world for a variety of programmatic, networking, and social events. From September 1 to 4 , 2011, scholars gathered to explore a thought-provoking program focused on the theme, "The Politics of Rights." The meeting was organized by program co-chairs Frances Hagopian, Harvard University, and Bonnie Honig, Northwestern University. The final meeting registration count was 6,287 . This venue followed from an expedited relocation of the meeting away from San Francisco, where it was originally planned, because labor actions there prevented us from reliably being able to perform.

In addition to more than 800 panels, many special events were held during the meeting. The awards ceremony recognized more than 30 individuals for their outstanding books, dissertations, and notable career achievements with 22 awards. The APSA Siting and Engagement Committee coordinated a focus on labor issues in Seattle's history, and hosted a tour of Seattle's rich labor history that was very well received. The presidential address was delivered by APSA president Carole Pateman, UCLA, "Participatory Democracy Revisited," followed by the 107th Annual Meeting Opening Reception. Additionally, lectures were given by APSA James Madison Award recipient Jane Mansbridge, Harvard University; John Gaus Award recipient Hal Rainey, University of Georgia; Arjun Appadurai, New York University; and Frances Fox Piven, City University of New York.

Siting and Engagement. One of the significant discussions in the association regarded the Annual Meeting's location in New Orleans and subsequent Annual Meeting sites. A permanent standing committee was formed to address the implications of where the association holds its meetings and to tie the theme of the meeting to its location. The Siting and Engagement Committee has recommended that at each site, APSA plan for an engagement "package" that would optimally emphasize events that would help members understand local and regional political concerns, issues, and contexts. The emphasis here would be on learning from the community, and, at the same time, to use our own experience to pose questions that cross the boundaries between particular issue areas and constituencies.

The committee foresees a coherent engagement program of at least three elements: (1) A major address by a high-profile speaker (writer, politician, community activist, journalist, or academic) who is able to introduce APSA members to the political issues of the community and, ideally, to provide an overview that addresses the intersection of issues and communities. The council also has approved, at the committee's request, budget authorization for fees for an appropriate major speaker as relevant to local circumstances. (2) A round table discussion of community activists, drawing from a range of issue and constituency backgrounds, asked to address a set of broad questions developed by the committee. (3) A local, politically engaged tour of the city, or some part of it, or the presentation of a visual guide to the city at the convention site, introducing members to politically relevant aspects of the city not readily seen by to convention-goers.

For the 2011 meeting this engagement process focused heavily on Seattle's labor history, as a reflection both of its significant role in that city and its relevance to our relocation there.

Awards. APSA awards cover excellence in scholarship and service, both in individual works and across careers. Over 22 awards were made at the APSA Annual Meeting for dissertations, research articles and monographs, and career contributions. APSA's Organized Sections offered another 117 awards. A significant development in recognition of excellence in our academic work in 2011 was the approval of a new APSA Distinguished Teaching Award. The award will honor outstanding contributions to undergraduate and graduate teaching of political science at two- and four-year and graduate-level institutions. It will recognize a series of contributions spanning several years or an entire career, although it may also recognize a single project of exceptional impact. To date, more than $\$ 50$,ooo has been pledged by APSA members to the endowment for this new award.

\section{Teaching and Learning Conference}

The Eighth Annual APSA Teaching and Learning Conference (TLC) was held February 11-13, 2011, in Albuquerque, New Mexico. The meeting theme was "Making Sense of Politics and Political Science." Using the working group format, the TLC allows small groups of scholars the opportunity to interact intensively and on a sustained basis on a common theme. To facilitate this interaction, all participants attend one working group for the duration of the conference. Additionally, the meet- ing features special workshops that focus on practical issues related to teaching. The 2011 conference featured 13 working groups and 20 workshops on a variety of topics. The 2011 TLC also featured plenary events, including a lunchtime roundtable "Strategies for Teaching Challenging Issues" and the Pi Sigma Alpha keynote address "Helping Students Make Sense of a Changing Political World," delivered by professor Jane Junn, University of Southern California. A host of exhibitors were also on hand for the meeting. The meeting concluded with a plenary session in which the attendees offered concrete suggestions on next steps for enhancing teaching and learning throughout the discipline and within their own academic communities. Prior to and following the meeting, registered attendees communicated and shared papers with fellow track members through APSA Connect.

As was the case in 2010, the 2011 TLC featured live, remote-participation technology provided by professor Derrick Cogburn and the COTELCO Lab (Syracuse University and American University). The sessions are currently available at www. apsanet.org/TLC. Through remote participation, the three plenary sessions were broadcast live online, allowing those who were unable to attend the meeting to join the meeting virtually. To disseminate the proceedings throughout the discipline, summaries from the 2011 TLC tracks were published in the July 2011 issue of PS: Political Science and Politics.

Looking ahead, the 2012 Teaching and Learning Conference will be held in Washington, DC, February 17-19, 2012. For the 2012 meeting, the TLC programming committee created two new tracks: "Conflict and Conflict Resolution" and "Teaching and Learning at Community Colleges." (The community college track had previously been a workshop theme.) A new workshop track, "Teaching Campaigns and Elections," has also been added. For more information on the upcoming 2012 TLC proceedings, visit www.apsanet.org/TLC.

\section{Small Research Grant Awards}

The APSA Small Research Grant Award, supporting scholarship by APSA members who are not in $\mathrm{PhD}$ granting departments, has also continued. The modest research funds are often leveraged by faculty at BA and MA degree granting programs and by independent scholars. Each year, APSA commits $\$ 19,000$ to support 
these grants. In 2011, APSA received 44 applications for the grant program. Nine recipients were funded at institutions such as University of Massachusetts, Dartmouth College, Bowling Green State University, and the US Naval Academy.

\section{Publishing}

Significant developments were underway in APSA publishing as well during the year. After an extensive competitive request for proposals process involving leading publishers, the association selected Cambridge University Press to continue its publishing relationship for APSA journals. The emphasis of the evaluation was based on financial return, circulation and subscription support and expansion, editorial services, and the facility to support new features and services, particularly online capabilities. We also considered the overall reputation of each publisher and "fit" with APSA journals. We feel Cambridge continues to be the best choice for the APSA journals and can report APSA journals are highly prized among publishers.

A search also was conducted for new editors of the American Political Science Review, following the wrap-up of the term of the editorial team at UCLA. The council completed its search at the end of this program year, and the new team will be announced shortly after this report goes to press.

With a very positive review in hand, the APSA council extended the editorship of Jeffrey Isaac of Perspectives on Politics for two years to round out a six-year term ending in the summer of 2015. The review committee noted the vision and energy he has brought to his role, the caliber of the staff he has assembled, and the intellectual initiative to shape what Professor Isaac calls the "political science public sphere, publicizing important scholarly topics, ideas, and innovations, linking scholarly authors and readers, and promoting broad reflexive discussion among political scientists about the work that we do and why this work matters" of the journal.

PS: Political Science and Politics continues its mission of highlighting the discipline's perspectives on contemporary politics, examining issues of relevance to the profession, and contributing to the content and direction of teaching. The year has included significant changes in the journal's editorial office. Barbara Walthall has joined the staff as the journal's managing editor. Robert J-P. Hauck continues as editor of $P S$, having partially retired from APSA.
Table 1

\section{Annual Meeting Registration}

\begin{tabular}{|c|c|c|}
\hline YEAR & ATTENDEES & LOCATION \\
\hline 1973 & 2,312 & New Orleans \\
\hline 1974 & 2,773 & Chicago \\
\hline 1975 & 2,478 & San Francisco \\
\hline 1976 & 2,295 & Chicago \\
\hline 1977 & 2,624 & Washington, DC \\
\hline 1978 & 2,373 & New York \\
\hline 1979 & 2,687 & Washington, DC \\
\hline 1980 & 2,745 & Washington, DC \\
\hline 1981 & 2,887 & New York \\
\hline 1982 & 2,205 & Denver \\
\hline 1983 & 2,859 & Chicago \\
\hline 1984 & 3,391 & Washington, DC \\
\hline 1985 & 2,842 & New Orleans \\
\hline 1986 & 3,602 & Washington, DC \\
\hline 1987 & 3,524 & Chicago \\
\hline 1988 & 4,161 & Washington, DC \\
\hline 1989 & 3,496 & Atlanta \\
\hline 1990 & 4,505 & San Francisco \\
\hline 1991 & 5,179 & Washington, DC \\
\hline 1992 & 4,998 & Chicago \\
\hline 1993 & 5,635 & Washington, DC \\
\hline 1994 & 5,902 & New York \\
\hline 1995 & 5,559 & Chicago \\
\hline 1996 & 6,055 & San Francisco \\
\hline 1997 & 6,391 & Washington, DC \\
\hline 1998 & 6,633 & Boston \\
\hline 1999 & 5,818 & Atlanta \\
\hline 2000 & 6,167 & Washington, DC \\
\hline 2001 & 6,492 & San Francisco \\
\hline 2002 & 6,432 & Boston \\
\hline 2003 & 5,894 & Philadelphia \\
\hline 2004 & 5,762 & Chicago \\
\hline 2005 & 6,537 & Washington, DC \\
\hline 2006 & 7,030 & Philadelphia \\
\hline 2007 & 6,929 & Chicago \\
\hline 2008 & 7,199 & Boston \\
\hline 2009 & 6,152 & Toronto \\
\hline 2010 & 7,311 & Washington, DC \\
\hline 2011 & 6,287 & Seattle \\
\hline
\end{tabular}

The APSA council has also approved an option to permit members to select only the online version of the APSA journals, foregoing print copies. This plan will be implemented starting in 2012. Separate choices will be possible for individual titles. This initiative responds to requests from members who already rely on online access only. APSA will develop new online tools for distributing information about content of new published materials.
Table 2

TLC Registration

\begin{tabular}{ccl} 
YEAR & ATTENDEES & \multicolumn{1}{c}{ LOCATION } \\
\hline 2004 & 113 & Washington, DC \\
2005 & 291 & Washington, DC \\
2006 & 258 & Washington, DC \\
2007 & 310 & Charlotte, NC \\
2008 & 330 & San Jose, CA \\
2009 & 239 & Baltimore \\
2010 & 250 & Philadelphia \\
2011 & 260 & Albuquerque \\
\hline
\end{tabular}

APSA continues to support the discipline with publications on careers, professional development, professional issues within the discipline, teaching materials, reports from the association, and directories. Sales of publications provide roughly $\$ 25$,ooo in annual revenue to the association for use in production of new titles as well as in support of the work of the association at large. In the past year, we released a new report from the APSA Task Force on Political Science in the 21st Century. In 2012 we look forward to a new edition of the career book and work on civic engagement, followed by a new internship guide in 2013 .

\section{STATE OF PROFESSION}

Following a low point in 2009, employment opportunities for new scholars have continued to strengthen. At of the end of October 2011, one-third more assistant professor job openings have been posted than at the comparable time of the recent low point two years ago, showing a gain over last year as well. Listings for IR positions remained the greatest proportion of all substantive fields (nearly 21\%), with American politics second (nearly 18\%) but continuing its slide from $25 \%$ in the early 200os. The placement picture is a bit more complex with just under half of the candidates for first-time placements on the market finding permanent academic positions, down $8 \%$ from the previous year. But these data have a one-year lag, and we expect current placement rates are higher.

As published in the 2009-10 placement report, the diversity of the doctoral students on the market in 2009-10 (our most recent data) was largely unchanged from the previous year. The proportion of female candidates increased $2 \%$ to nearly $40 \%$ of the group; the pool was $81 \%$ white, $5 \%$ 
Table 3

\section{APSA Section Counts (As of November 2011)}

\begin{tabular}{|c|c|c|}
\hline SECTION \# & SECTION NAME & \# OF MEMBERS \\
\hline 01 & Federalism and Intergovernmental Relations & 391 \\
\hline 02 & Law and Courts & 742 \\
\hline 03 & Legislative Studies & 625 \\
\hline 04 & Public Policy & 983 \\
\hline 05 & Political Organizations and Prties & 507 \\
\hline 06 & Public Administration & 470 \\
\hline 07 & Conflict Processes & 460 \\
\hline 08 & Representation and Electoral Politics & 358 \\
\hline 09 & Presidency and Research Group & 358 \\
\hline 10 & Political Methodology & 1,044 \\
\hline 11 & Religion and Politics & 547 \\
\hline 13 & Urban Politics & 354 \\
\hline 15 & Science, Technology, and Environmental Politics & 376 \\
\hline 16 & Women and Politics & 643 \\
\hline 17 & Foundations of Political Theory & 806 \\
\hline 18 & Information Technology and Politics & 267 \\
\hline 19 & Informational Security and Arms Control & 518 \\
\hline 20 & Comparative Politics & 1,578 \\
\hline 21 & European Politics and Society & 457 \\
\hline 22 & State Politics and Policy & 462 \\
\hline 23 & Political Communication & 449 \\
\hline 24 & Politics and History & 636 \\
\hline 25 & Political Economy & 720 \\
\hline 27 & New Political Science & 483 \\
\hline 28 & Political Psychology & 503 \\
\hline 29 & Political Science Education & 498 \\
\hline 30 & Politics, Literature, and Film & 326 \\
\hline 31 & Foreign Policy & 637 \\
\hline 32 & Elections, Public Opinion, and Voting Behavior & 884 \\
\hline 33 & Race, Ethnicity, and Politics & 589 \\
\hline 34 & International Politics and History & 441 \\
\hline 35 & Comparative Democratization & 671 \\
\hline 36 & Human Rights & 415 \\
\hline 37 & Qualitative Methods & 860 \\
\hline 38 & Sexuality and Politics & 253 \\
\hline 39 & Health Politics \& Policy & 259 \\
\hline 40 & Canadian Politics & 233 \\
\hline 41 & Political Networks & 284 \\
\hline 42 & Experimental Research & 406 \\
\hline
\end{tabular}

African American, 4\% Asian/Pacific Islander, and $4 \%$ Latino/a. Placement for women in permanent academic jobs was greater than for men, as it was in the previous year, but women were placed as ABDs nearly twice as often as men and took positions at BA granting institutions more often than their male colleagues. Among race and ethnicity categories, Latino/as outplaced all other groups in permanent academic positions, and were least likely to be unemployed by the summer of 2011. In contrast, African American job candidates experienced a significant decline in placement in permanent academic positions (from $65 \%$ in $2008-09$ to less than $50 \%$ in 2009-10), and were hired in BA granting departments more than any other group and began permanent positions more often than the others as ABDs without the degree completed. They also placed least often in postdoc positions. Women of color were more successful on the market than their white female colleagues, with Latinas and the African American women placing at the greatest rates. African American women placed least often at $\mathrm{PhD}$ granting institutions, most often at BA granting institutions, and had the highest unemployment rate of women of color. International candidates filled $40 \%$ of the postdoc positions in 2009-10, and 38\% placed in permanent academic positions (for context, $45 \%$ of US citizens placed in these positions).

\section{APSA AS AN ORGANIZATION}

As the financial operations report shows, APSA is an over-\$6-million-a-year organization, with active governance and association management activities. There are 27 full-time staff, and the association owns two buildings in the Dupont Circle neighborhood of Washington, DC. The main building houses all APSA staff (other than two journal editorial offices), and compatible organizations lease the unused space. The second building provides options for future expansion and serves as an investment. Although the main building is slated for a significant upgrade to the HVAC system in 2012-13, current plans and designs permit us to continue working in the facility while the work is completed. This will then free up space where the current, obsolete, boiler is housed and open up other parts of the office. An engineering study is also underway to review the possibility to create a larger public space in the building.

\section{Governance}

APSA governance focuses on the APSA council, but basic authority rests with the membership. Actions moved forward at the all-member business meeting held at each annual meeting are presented to the full membership by e-mail ballot. This year at the 2011 Annual All-Member Business Meeting, several proposed constitutional amendments were considered, all speaking to the way in which nominees are selected for council election. One amendment was proposed by the council itself, for the nominating committee to name one-and-onehalf candidates for each council seat, and name one for president-elect, plus freeing up a seat for the council to fill on its own initiative. A second amendment, submitted by a petition of members, called for an elected nominating committee and two candidates for each open seat including president-elect. After active member debate 
neither amendment received the $40 \%$ minimum support from the assembly to go forward to the all-member ballot. An amendment to incorporate a language calling on the nominating committee to produce a diverse slate of nominees did go forward.

Also at the business meeting, candidates for president-elect, vice president, secretary, and treasurer were elected uncontested. Jane Mansbridge was elected president-elect, and Morris Fiorina, Kerstin Hamann, and Niraja Gopal Jayal took office as vice-presidents. Lisa Martin was elected as secretary and Jonathan Benjamin-Alvarado as treasurer. For council seats, seven candidates were certified based on petitions by members, and joining those proposed from the nominating committee, producing 15 candidates for eight seats. The matter moved forward to the all-member ballot in October. The election results are announced in this issue of PS (see Gazette, this issue) and on the APSA website.

\section{Data and Surveys}

Another core infrastructure activity of the association is assembling and maintaining data about the profession. These data are developed from a census of academic political scientists maintained in the APSA database in cooperation with political science departments, a survey of political science departments, and studies of job announcements and reports of placement. APSA also tracks data gathered by other sources, such as the National Science Foundation reports on PhD's produced.

In 2012, APSA took steps to revamp this data collection, including changing vendors for greater control over survey design and data gathering and revising survey instruments. The 2010-11 departmental survey administered in mid-August, a bit later this year on advice of Committee of Departmental Services, closed October 2011 with a $19 \%$ response rate-on par with last year. This survey marks the first set of revisions to the instrument. The 2010-11 placement survey was opened in November 2011. A revamped salary survey will be undertaken in 2012. The APSA council has also authorized an all-member survey during the upcoming year, as a means for guiding long-range planning for the association.

\section{Online Engagement}

The APSA website and online-based technologies serve as an integral tool for the association's communication, data collection, and e-commerce strategies. These tools are used by APSA programs as well as the council, committees, organized sections, related groups, and other organizations. The APSA website supports large volumes of traffic annually including more than 11,0oo proposals to the APSA conferences; $\$ 3.367$ million in online purchase transactions annually (averaging \$259,075 per month) for membership, registrations, publications sales, and donations; and more than 2,ooo pages of web content managed by APSA staff.

We are continually improving the site with the needs of members, APSA programs and staff, and public in mind. Notable developments in 2011 include improved online forms to apply to APSA programs and for members to update personal information in the APSA database, mobile optimized Annual Meeting online program, and a new "remember me" login option. We continue to see a large volume of traffic at 1.6 million visits annually of which 200,000 were unique visits, marking a $6.89 \%$ increase over the prior year. We believe the sustained interest in the site demonstrates the value of the information hosted on our site for members, prospective faculty, and student members as well as the wider public around the world. Our most popular pages and searches driving users to our site relate to career and educational opportunities in political science (undergraduate and graduate), interest in e-jobs specifically, scholarly research, and specific fields and specialization.

Members may also have noticed improvements we have made in our e-mail communications, aided through the use of new software. The new system provides more robust tools to build professional, visually appealing communications and to ensure better deliverability.

APSA Connect. In February 2010, APSA officially launched APSA Connect, an online professional networking website for political scientists. All APSA members have an account and profile on APSA Connect. We encourage you to update your profile and make use of this resource to connect with colleagues by going to www.apsaconnect.org.
The site supports online private communication among APSA committees and sections and across APSA programs and activities. APSA Connect supports private discussion lists, document sharing, and mini-webhosting tools with flexibility to offer private, semi-private, and public group tools. APSA Connect also functions as an online directory with Web 2.o capacities to conduct robust searching and to connect with other scholars with shared interests. APSA Connect offers improved website hosting and content management services to organized sections and other groups. We are working with an external firm to redesign layout of the main APSA Connect pages to improve usability and design.

Outreach on Social Networking Sites. In addition to the APSA website and APSA Connect, APSA maintains a presence on leading social networking sites: Twitter, LinkedIn, Facebook, YouTube, and Flickr.

We aim to maintain an appropriate presence on these sites that, for the most part, serve as a way for members of the APSA community to connect and as a tool for the association to share information and news in the profession. For example, we circulate key association news on Twitter to our roughly 1,000 followers who then often re-tweet news to their followers. Several APSA programs have subgroups on these sites including the Africa Workshop Program, Congressional Fellowship Program, and PS: Political Science \& Politics. Individuals who choose to follow or join groups seem to use social media as a means to stay current on APSA or disciplinary news or to identify themselves as a "fan" of APSA or political science.

\section{CONCLUSION}

This extensive outline of association activities, in support of members, of scholarship and teaching, and of the infrastructure and commons of the discipline is not the whole story. APSA involves an active community of committees, caucuses, organized sections, related groups, task forces, and working groups whose activities are reported online and in $P S$, and whose energy fuels much of the activity described in the annual report. It is an impressive community, with remarkable vigor and commitment to common purpose. And, it is a pleasure to submit an annual report on everyone's behalf. 